\title{
The Severan Commemorative Relief at Cyrene. The portraiture
}

\author{
To the dear memory of the late Professor D. E. Strong
}

On my first visit to Cyrene in summer 1972 I was so intrigued by the figurative relief standing on the south side of the so-called Valley Street, immediately to the east of the modern village of Shahat, that I decided to include it in my doctoral thesis. ${ }^{1}$ I visited the site in the distinguished company of the late Prof. D. E. Strong, who was then my research supervisor, and Mr. Philip Kenrick. We spent together some hours in front of this fascinating monument discussing a number of points concerning the architecture of the building to which it belonged, the identification of the figures, the iconography of the then hypothetical portraits, and the reading of the inscription. A full description and discussion of the monument were given by Professor Strong in a lecture delivered at the British Museum on the occasion of the opening of the Exhibition of Libyan Antiquities on 14th June, 1973, and later published in the Society for Libyan Studies Report. ${ }^{2}$ I returned to Cyrene in summer 1973 in order to make a more thorough examination of the relief and to produce a number of detailed photographs of the heads. ${ }^{3}$ The contents of this article are the result of these observations and the stimulating discussions I had with Professor Strong on the subject.

For a comprehensive description of the relief I refer the reader to Strong's contribution in the Fourth Annual Report, but it is appropriate to recapitulate briefly. The relief in question constituted the figured frieze of the entablature of a monumental gateway resting on Corinthian columns. ${ }^{4}$ Beneath the frieze, which must have been more than $11 \mathrm{~m}$ long, ran an inscription in two lines of standard monumental Greek letters. ${ }^{5}$ All the architectural elements, including the frieze, are carved on a very gritty and shelly limestone. The state of preservation is very poor: the figures on the right hand block are almost completely lost and elsewhere heads and limbs have fallen off, in some cases being cemented back. The best preserved are the central figures, but even here the sugary limestone has eroded to some extent (Fig.Ia).

The relief depicts combat scenes between Romans and barbarians who, from their oriental headgear, may easily be identified as Parthians. ${ }^{6}$ Though Severus' title of Parthicus does not figure in the incomplete inscription, the frieze almost certainly commemorates Septimius' Eastern campaigns. But instead of the episodic treatment of the subject, as on the large panels of the Arch of the Severi in the Roman Forum, ${ }^{7}$ we have here an ideal synthesis of the whole war in one scene. The issue of the war is already decided, the Romans are victorious and the enemy is in flight, collapsing to the ground, or else already captive. A similar synthetic treat ment appears in the battle scene of the Great Trajanic Frieze, ${ }^{8}$ as opposed to the narrative and episodic nature of Trajan's Column. ${ }^{9}$ The composition is more or less symmetrical with the main group in the centre flanked by minor individual combats, the whole scene being framed by two trophies, one at either end of the frieze. Some of the warriors fight on horseback and some on foot but no distinction of height is made between them. The horses and their drivers are consequently somewhat reduced in scale.

There are two main points on which I disagree with Professor Strong: the identification of Septimius Severus and the interpretation of the curious figure in the background above the sitting captive in the left hand slab. The issue of the first point depends to some extent on that of the second. I find good reasons to support Professor Strong's identification of Caracalla and I dare to propose a new identification, that of the latter's brother, Geta.

Donald Strong saw the Emperor Severus in the naked warrior standing on the right end of the left hand slab (Fig.Ib). The figure is shown in three-quarter view from behind. The left arm is stretched forward holding a round bossed shield against a mounted barbarian who is fleeing to the left. The right arm is stretched back ready to strike with the unsheathed sword. The 
empty scabbard hangs back along the right thigh. Strong would have expected the Emperor to appear, "as on the Great Trajanic Frieze, riding against the enemy or, in military dress, crowned by victory at the conclusion of the campaign". ${ }^{10}$ But, failing to recognize him in any of the surviving horsemen, he "turns naturally to the nude warrior who punctuates the action so decisively, just, one notes, without prejudice, above the word Septimius on the architrave".

In doing this the eminent art historian failed to consider two important factors, one of a compositional, the other of an iconographic nature. So far as I can remember, never, in Roman official reliefs, is the principal figure removed from the centre of the composition and, at the same time, facing away from it. The position of the body facing obliquely into the background is also very unusual, especially at this late date when frontality of the principal figures had already made great strides towards becoming a universal characteristic in the art of the Roman Empire. Secondly, there is no portrait attributable to Severus showing him beardless. Again, to deprive the Emperor of such an essential characteristic physiognomic feature on a public monument would seem to me to be departing too much from the established norm and would have rendered the identification of the Imperial figure by the viewer far too difficult. There is no doubt, on the other hand, that our naked "hero" is clean shaven. One might object to this assertion by suggesting that the present appearance is possibly due to weathering. A close examination of the head, however, and our illustration (Fig.IIa) show clearly that no erosion has taken place on the chin and left cheek; the surfaces there still preserve the claw-chisel treatment noticeable in many other unweathered areas. All this is proof enough that this man could not be identified with the Emperor. Besides, the nakedness of the figure ill-fits the Roman decorum and respectability with which emperors like the Antonines and Severus surrounded themselves, even more so on a public monument. The combination of Greek nudity and Roman portraiture in the bronze statue of Septimius from Cyprus ${ }^{11}$ is certainly discordant with the Roman officially acceptable tastes at the end of the second century A.D.

Over and above this, none of the facial features in the head of this naked figure bears any resemblance to those of Severus' portraits. The face presents a large nose under a slightly sloping forehead. The eye is apparently cut in the same way as those of the other figures but only the spherical shape of the eyeball with the central drilled hole survives. The mouth is opened by a deep and wide drilled groove. A rather unusual feature is the short and rigidly straight naso-labial depression from behind the nostril to the corner of the mouth.

Professor Strong found his most conclusive evidence for this identification in the figure in the background behind the nude warrior. According to him it "can be nothing other than a Victory carrying a shield and stretching out her arm to crown him (Severus)" and "only the eye of a very myopic faith is required to see her". ${ }^{12}$ Now I happen to be just slightly myopic and, to make sure my eyes did not deceive me, I scrutinised the figure at close quarters and from a distance for several minutes. The more I examined it in general and in detail, the more I was convinced that it was not a Victory. But what else could it be? The only other alternative I can think of, and surely the more plausible one, is that it is a trophy, one of those curious objects set up to celebrate some military victory and consisting of a wooden stake, often crossshaped, dressed up with enemy armour. Such trophies are frequently found represented in relief both on private monuments, such as sarcophagi, ${ }^{13}$ and, much more often, on public ones. ${ }^{14}$ Indeed, it has already been noticed that two similar trophies enclose the battle scene at either end of this very same relief. What is visible behind our nude "hero" is indeed a shield, but it is sustained by an inanimate object, the left arm of the trophy. The right arm is thrust towards the head of the warrior, but not to crown him, while the battered head is very likely a worn out helmet. And, to confirm our interpretation, a barbarian captive in a sleeveless tunic and oriental headdress is sitting at its foot with hands tied behind his back, a perfect parallel to the captives on the ferculum in the frieze from the temple of Apollo in Campo ${ }^{15}$ and the nude Galatian captives on the sarcophagus from the Via Appia in the Museo Capitolino. ${ }^{16}$

The basic difference between Greek and Roman commemorative relief sculpture is that in the 


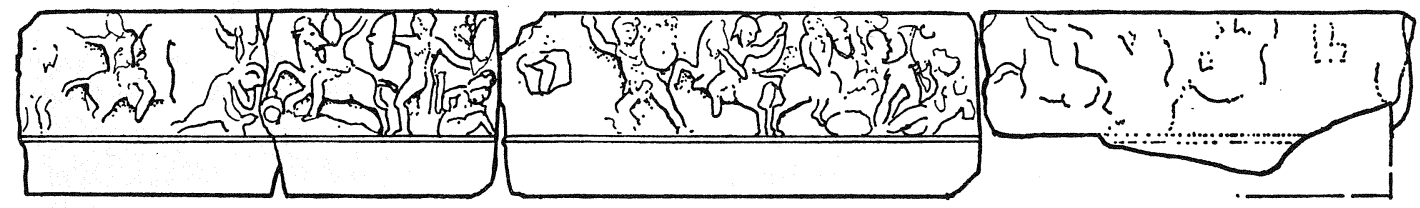

a.
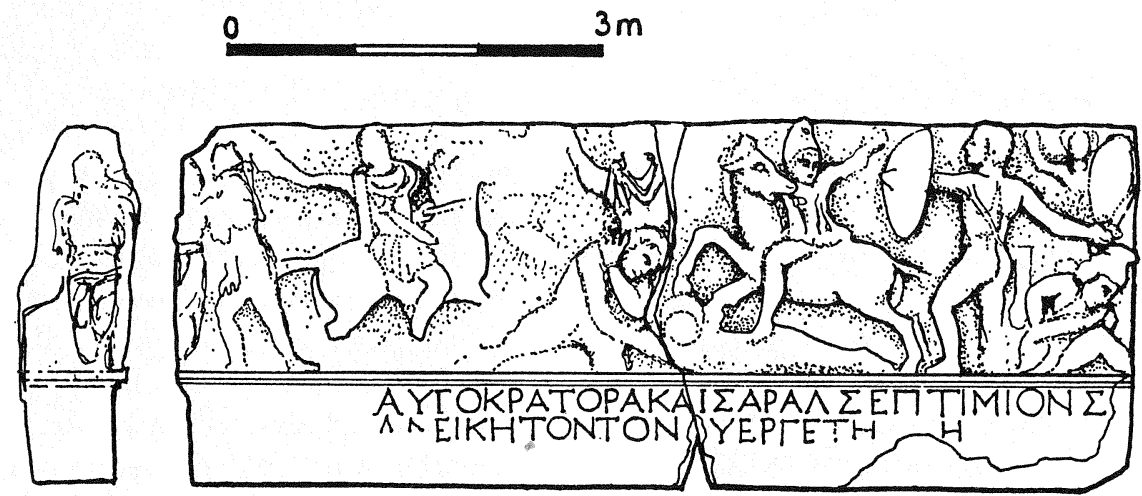

b.

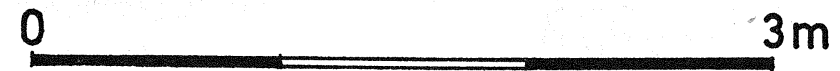

S.G.

c.

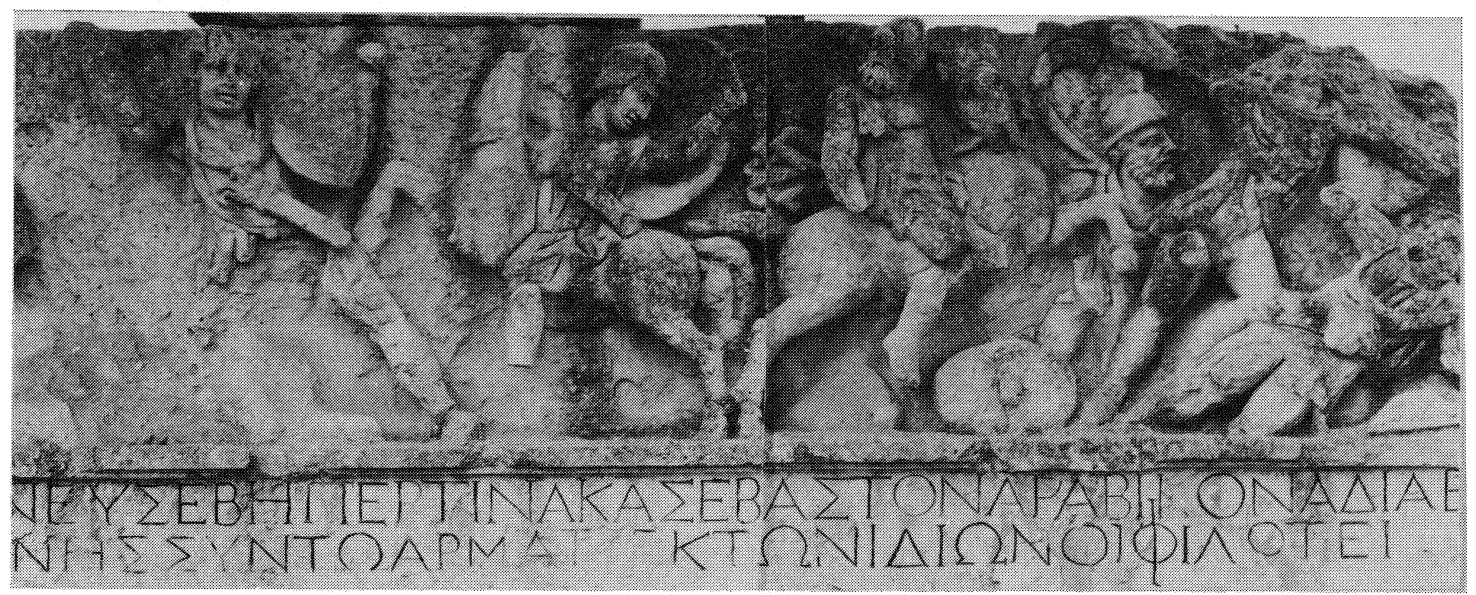

Fig.1. Frieze from Market Theatre, Cyrene.

a. Drawing of general view of the frieze from the Market Theatre, Cyrene

b. Left hand slab showing nude warrior.

c. Middle slab showing Imperial group.

former the events celebrated are symbolised by a mythological or legendary theme whereas in the latter the actual events are depicted, with the historical personages involved being recognizably present. Professor Strong was, therefore, right to assume that the Emperor must be manifestly present in the frieze. But having eliminated his identification with the heroic figure, where are we to find him? I, for one, would look for him where Professor Strong set out to do so before he focused his attention on the naked "hero", namely, among the horsemen. And there I find him, in the only surviving bearded horseman on the middle slab, almost at its centre (Fig.Ic). Unlike Trajan in the battle scene on the Great Frieze, he is not actively aggressive: he does not charge into the falling enemy, nor does he raise his arm to strike the fatal blow on him. But his pose is equally majestic in its calm demeanour. He dominates the entire scene: the movement of the horse to the right embraces that side of the relief, while the turn of the Emperor's 
head backward encompasses the left side. He is in perfect control of the whole situation. Far from being a "fleeing barbarian", this "venerable bearded figure" is a Roman, recognizable as such from his attire consisting of a cuirass, with loose hanging flaps, and a paludamentum, whereas all the barbarians in this relief wear a simple tunic. As on the Trajanic Frieze, the Emperor's cloak flutters in the air behind him.

Equally convincing as an argument in favour of the identification of this horseman with Severus is, to my mind, the physiognomy of the figure. In spite of its bad state of conservation this head (Fig.IIb) can be easily fitted into Severus' iconography. ${ }^{17}$ Unfortunately only half of the face survives and not in a very good condition. The right eye is rendered by a bulging hemispherical eyeball with a round deep hole in the centre for the iris. This is the usual way of representing the eyes in the Cyrene relief, but in this case the eyeball stands out somewhat grotesquely between the deep depressions on either side, since no trace of the eyelids has survived. As in the other heads a deep groove separates the lips, here dipping down at the corners of the mouth to offset the moustache and lower lip. A close examination of the only surviving cheek, which still preserves some traces of the rough finish produced by the claw-chisel, reveals the movement of the facial muscles suggested by the moulded surfaces. Though the crude style and rough surface treatment impart a certain generic appearance to the head, with a due amount of mental reconstruction Severus' characteristic facial features stand out clearly. The forehead and the hair above it are missing, but a close view of the beard from the front reveals clear traces of vertical separating channels, recalling the characteristic partition of Septimius' beard, which he seems to have imitated from his Antonine predecessor, Marcus Aurelius. ${ }^{18}$ I do not think it is possible to reduce this identification more precisely to a distinct portrait type of Severus but a comparison with his other portraits in relief, such as those on the Severan Arch at Lepcis and the Arch of the Argentarii ${ }^{19}$, is very revealing.

The identification made by Donald Strong which I accept wholeheartedly is that of Caracalla. The elder of the two Severan princes is to be seen in the young man, with boyish features, defeating a mounted enemy soldier immediately to the left of our bearded horseman (Fig.Ic). $\mathrm{He}$ is wearing a paludamentum over a short cuirass. His sword, with a hilt in the shape of an eagle's head, is in its scabbard hanging in front from a belt over his right shoulder. The missing weapon he brandishes in his right hand must therefore be a spear. In his left hand he thrusts forth a strange object, at the mere sight of which both his adversary and the latter's horse are thrown aback. The young warrior is grabbing this object by the upper edge and using it as a shield. Strong's ingenious interpretation of it as an aegis ${ }^{21}$ is most acceptable since this divine attribute is often worn by Emperors and members of the Imperial family especially on gems and coins. $^{21}$ It could also possibly be the lion's skin, the attribute of Hercules with whom several Emperors, from Commodus onwards, liked to identify themselves. ${ }^{22}$

The young man stands facing the spectator in a somewhat diagonal position, but his head is slightly turned to the right. He displays a full, well-fed face with heavy jaws and chin (Fig.IIc). His abundant hair consists of thick curls separated by frequent deep grooves and holes made by the drill. The eyes, of which the right one is the better preserved, are carved in the usual manner, but here the inner corners are far more deeply excavated, thus isolating better the spherical eyeball which is also perforated by a round hole. The deep dark canal that marks the mouth is cut with greater care than usual and it follows the sinuous shape of the fleshy lips. The drill has been used also to create the strong shadow between the lower lip and chin, thus emphasizing the fleshiness of the former and the prominence of the latter.

Although carved on such an unusual material as this gritty limestone, and expressed in such different style and technique, all the facial traits of this young warrior agree perfectly with the iconography of Caracalla, generally carved on marble either in the round or in relief. ${ }^{23}$ His head seems to fit best in the earliest of Caracalla's portrait types, the 'Arch of the Argentarii type' (Typus Argentarierbogen). ${ }^{24}$ Portraits of the young prince which present very close iconographic parallels to the Cyrene head are the one in Toulouse, ${ }^{25}$ the Vatican head, ${ }^{26}$ and the portrait in the 


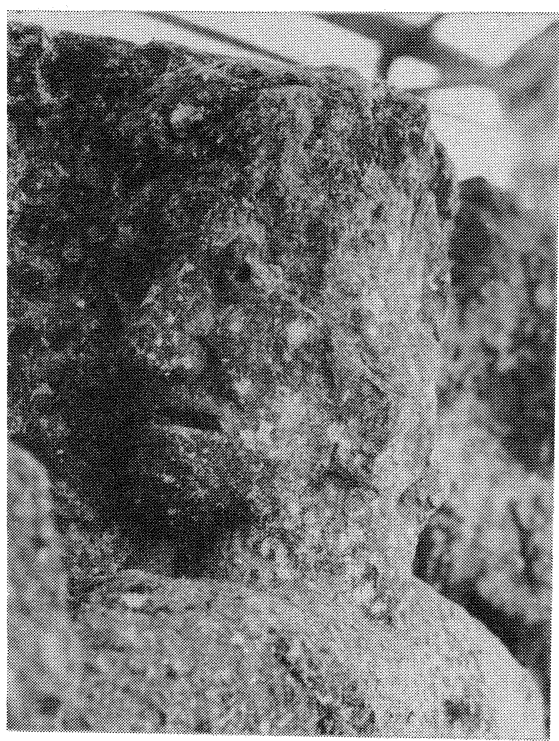

a. Nude warrior. Detail of head

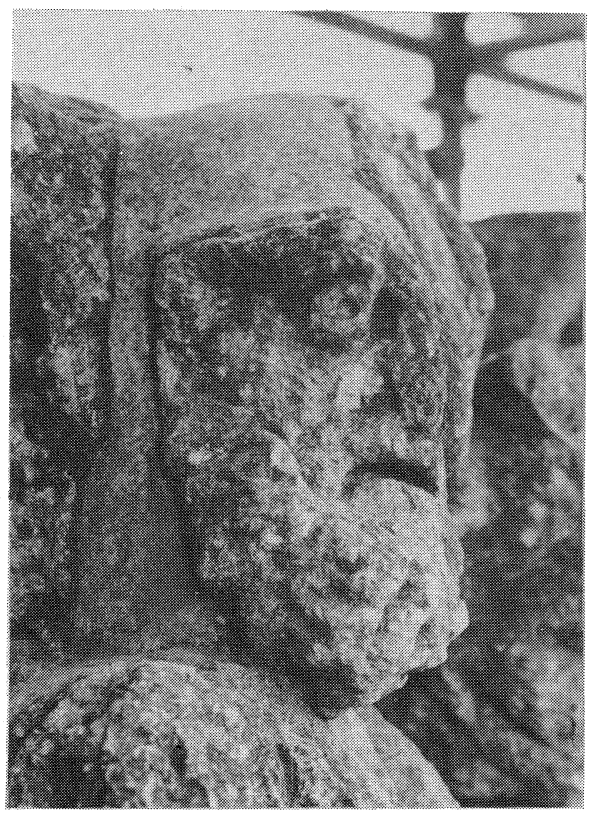

b. Septimius Severus. Detail of head.

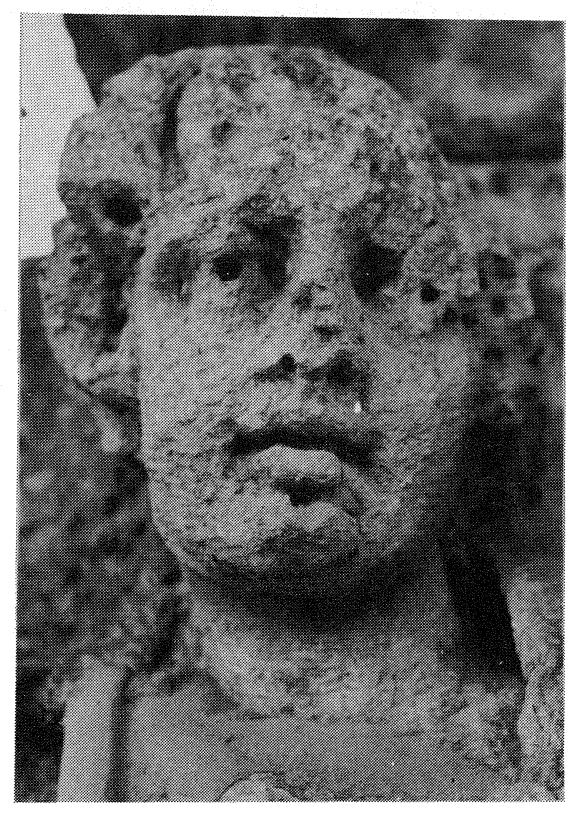

Fig.II

c. Caracalla. Detail of head.

Museo Nazionale in Rome. ${ }^{27}$ But the best comparison is, perhaps significantly, with the prince's portrait cut in relief on the Arch of the Argentarii, which in fact gives the name to this early iconographic type of the young Caracalla. All these portraits are characterized by the rounded, childish face and the long agitated hair which forms a definite pattern of locks on the forehead, unfortunately missing in our head. The resemblance to Caracalla's head on the Dextrarum Iunctio frieze on the Arch of Lepcis is less obvious. ${ }^{28}$ The structure and general features of the face are, nevertheless, the same: heavy jaws and chin, protruding lips and wide flat nose. The hairstyle in the Lepcis head seems to be shorter than usual. 
The teenage appearance of our warrior agrees well with the age of Caracalla in A.D. 203, the year around which the creation of this Cyrenaean monument is placed. In 203, at the age of $17^{29}$ the elder of Severus' two sons had already participated in the Eastern wars with his father and brother, had been proclaimed Imperator Designatus and Augustus, and had occupied the office of consul. It is certain that he is represented in his father's company in the large panels on the triumphal arch in the Roman Forum, ${ }^{30}$ which commemorate Severus' Eastern campaign, and therefore, his presence as a soldier prince, and in close vicinity to his father, is to be expected on the Cyrene relief. The figure that fits ideally all the iconographic and compositional requirements is certainly our young warrior. The eagle-headed sword hilt might very well be distinguishing him as Imperator Designatus. ${ }^{31}$

The new identification I wish to propose is that of Geta, Caracalla's younger brother, whom he murdered later, soon after Septimius' death. Born in A.D. 189, Geta was barely 8 years of age when he set out east with his father and brother for the war against the Parthians. The year after, in 198, when Caracalla was given the title of Augustus, Geta succeeded him as Caesar. If Severus and Caracalla are present in the Market-Theatre relief - as we have tried to show - it is natural to expect the other prince to be present. From 198 onwards, more so towards the end of his reign, Severus associated his younger son with Caracalla as co-heir to the Imperial power. The only clue to his identification is offered by the compositional scheme of the frieze. I have already tried to prove that the Imperial group, so far consisting of Severus and Caracalla, is placed right in the centre of a balanced composition. The symmetry of the latter is enhanced even further if, as I think, Geta is to be identified in the headless figure in the foreground immediately to the right of Severus (Fig.Ic). With its diagonal position, slanting in the opposite direction, it balances perfectly the figure of Caracalla on the other side of the Emperor. Like his brother, Geta is wearing a short cuirass and a mantle pinned on the right shoulder. He is also shown in a victorious attitude striking down with a spear at a fallen enemy. His sword hangs idle in the scabbard across the chest, but its hilt is a plain one; which suggests that the eagleheaded sword was the prerogative of the elder prince alone.

If we survey the official commemorative monuments erected during Severus' reign, both in Rome and in the provinces, we find that the two princes are invariably represented together in the company of their father, in the majority of cases one on either side of the latter. In all the scenes on the great panels of the Arch in the Forum Romanum, for example, the Emperor is flanked by his two sons, even if they are not individually identifiable due to the loss of their heads. ${ }^{32}$ It is certain that Geta was also portrayed on the Arch of the Argentarii in the Forum Boarium, both in one of the larger reliefs, and on the praetorian standards in the small reliefs. ${ }^{33}$ There, however, his portraits have been purposely chiselled off. On the Severan Arch in Lepcis Magna, finally, Geta appears in the middle between his brother and father in the Dextrarum Iunctio frieze and alone, being crowned by a Victory, on one of the smaller panels. ${ }^{34}$ The two princes flanking Severus appear on the chariot in the Triumphal Procession frieze and in one of the smaller reliefs, showing a sacrificial scene. ${ }^{35}$ Even the inscriptions of the two Roman arches made it a point that Geta was mentioned along with Caracalla, and the present absence of Geta's names and titles is due only to their having been erased after his murder and damnatio memoriae by Caracalla. ${ }^{36}$

It is therefore only natural to expect Geta to appear on the Cyrenaean relief, even if it is unlikely that his name appeared in the inscription since only Septimius is mentioned there. Even Strong had no doubt that the more youthful figure of the younger prince was present in the relief, but he failed to identify him in any of the figures and suggested that his absence was probably due to his damnatio memoriae. The figure we have identified as Geta is indeed headless but it may never be possible to tell for certain whether it was struck off on Carcalla's instructions or destroyed by accident or natural weathering. Had Strong identified Severus correctly, as he did Caracalla, I am sure he would have agreed with the suggested identification of Geta.

A. Bonanno 
1. Later published as A. Bonanno, Portraits and other Heads on Roman Historical Relief up to the Age of Septimius Severus (BAR, Oxford 1976).

2. D. E. Strong "Septimius Severus at Lepcis Magna and Cyrene", The Society for Libyan Studies, Fourth Annual Report (1972-3), 27-35, pls.VII-X.

3. I am grateful to the personnel of the Antiquities Department of Benghazi and Cyrene for their kind help and permission to photograph the relief.

4. For a description of the relief and the building to which it belonged see, besides Strong; H. Sichtermann, $A A$ (1959), 284-91, Figs.25-28; T. Kraus, Das römische Weltreich (Berlin 1968) 238, no.233 (H. von Heintze); C. C. Vermeule, Roman Imperial Art in Greece and Asia Minor (Cambridge, Mass. 1968) 79-80, 93; R. G. Goodchild, Kyrene und Apollonia (Zurich 1971) 138 ff., Figs.84-87.

5. It records the erection of a statue of Septimius Severus in a chariot by a group of citizens from their own private funds (EK T $\Omega$ N I $\Delta \mathrm{I} \Omega \mathrm{N})$. The text as reproduced by Strong in Fig.1, p.29 needs one or two slight corrections. Instead of EY $\Sigma$ EBH ITEPTINAKA read EY $\Sigma E B H$ ПEPTINAKA. Instead of IIAOTEI (or $Ф \Lambda$ AOTEI, as on p.30) read $Ф$ I $\Lambda$ OTEI.

6. Similar caps are worn by the Parthians on the Severan Arch in the Roman Forum: R. Brilliant, The Arch of Septimius Severus in the Roman Forum, MAAR 29 (Rome 1967) pls.46c, 48, 50-9, 78, 81.

7. Ibid. $167 \mathrm{ff}$. pls. $60 \mathrm{ff}$.

8. M. Pallottino, "Il grande fregio di Traiano", Bull-Comm 66 (1938) 17-56. W. Gauer, "Ein Dakerdenkmal Domitians. Die Trajanssäule und das sogenannte grosse trajanische Relief', JdI 88 (1973) 318-50.

9. K. Lehmann-Hartleben, Die Traianssäule (Berlin \& Leipzig 1926); L. Rossi, Trajan's Column and the Dacian Wars (London 1971).

10. Strong, op. cit. 33 .

11. Ibid. pl.IX.

12. Ibid. 33 .

13. E.g. the sarcophagus portraying a battle against Galatians in the Capitoline Museum and the sarcophagus of one of Marcus Aurelius' generals from Via Casilina in the Museo Nazionale, Rome: R. Bianchi Bandinelli, Rome, the Centre of Power (London 1970), Figs.341, 345.

14. Such as the Lagina frieze: A. Schober, Der Fries des Hekateions von Lagina (Istanbuler Forschungen, 2 1933) pl.XI. See also $E A A$ VII (1966) 996-8 s.v. "Trofeo" (Mansuelli). For the Arch of Severus in Lepcis see Brilliant $o p$. cit. Fig.51, and R. Bartoccini, "L'arco quadrifronte dei Severi a Lepcis" AfrIt 4 (1931) Fig.32. Two such trophies carved in the round now stand on the Capitol: Bianchi Bandinelli op. cit. Fig. 247.

15. Bonanno, op. cit. pl.28

16. Bianchi Bandinelli, op.cit. Fig.341.

17. For Severus' iconography see A. M. McCann, The Portraits of Septimius Severus, MAAR 30 (Rome 1968); D. Soechting, Die Porträts des Septimius Severus (Bonn 1972).

18. For Marcus Aurelius' portraiture see M. Wegner, Die Herrscherbildnisse in Antoninischer Zeit, Das Römische Herrscherbild II 4 (Berlin 1939).

19. Bonanno, op. cit. pls.281, 284, 286, 291-2, 301, 303.

20. Strong, op. cit. 34.

21. A. Alfoldi, "Insignen und Tracht", RM 50 (1935) 121; H. Mattingly, Coins of the Roman Empire III, xxiii; E. Babelon, Catalogue des camées antiques (Paris 1897) pl.XXXIV.

22. C. C. Vermeule, "Commodus, Caracalla and the Tetrarchs. Roman Emperors as Hercules", Festschrift für Frank Brommer (Mainz 1977).

23. See L. Budde, Jugendbildnisse der Caracalla und Geta (Münster 1951); H. B. Wiggers-M. Wegner, Caracalla bis Balbinus. Das Römische Herrscherbild III 1 (Berlin 1971).

24. Ibid. 17-22.

25. Musée Saint Rymond 30156: Ibid. 87, pl.3b.

26. Sala dei Busti 347: Ibid. 83, Budde op. cit. pls.15a, 17a.

27. No.641: Wiggers, op. cit. 79-80, pls.1a-b, 5a; Budde, op. cit. pl.18.

28. Wiggers op. cit. 14-6, 88, pls.6, 7c; Budde op. cit. 9, pl.6b.

29. Caracalla was born in 186. Strong is wrong in saying he was 13 years of age in A.D. 202.

30. Brilliant, op. cit. 171-82; Bonanno, op. cit. 143-4.

31. Strong, op. cit. 33-4.

32. See note 30 .

33. D. E. L. Haynes-P. E. D. Hirst, Porta Argentariorum (London 1939) 20-2, Figs.11-2, 22-3; Bonanno, op. cit. 148 .

34. Ibid. $150-5$ pls. 285,307 .

35. Ibid. $150-5$ pls. $290-1,300$.

36. Brilliant, op. cit. 91-5; Haynes, op. cit. 3-11. 